\title{
BERÁCS József
}

\section{OKTATÁSI HUB A LÁTHATÁRON LOGISZTIKAI TAPASZTALATOK TANULSÁGAI}

Az itt következő tanulmány a felsőoktatás nemzetközi versenyképességének vizsgálatába ágyazva azt elemzi, hogy a XXI. század információs és logisztikai technológiáinak birtokában milyen lehetőségei vannak a feltörekvő országoknak. Az egyetemek és különösen a kutató egyetemek koncentrációja a fejlett országokban, elsősorban az Egyesült Államokban (lásd pl. a közgazdasági Nobel-díjasok egyetemi hátterét), valamint a kereslet várható növekedése a fejlődő világban (pl. Kína) felveti a kormányzati és a piaci erők összehangolásának szerepét a kereslet és a kínálat alakulásában. A Dubai Knowledge Village üzleti alapon tervezett új egyetemi rendszere szolgáltatja a hátteret ahhoz, hogy a szerző elemezze a felsőoktatást, mint szolgáltatást. A szolgáltatásra mint romlandó, nem készletezhető termékre vonatkozó előítéletek (mítoszok) felszámolását alkalmazza a felsőoktatási tevékenységre. A logisztikai gondolkodás és a piaci orientáció vezet el ahhoz, hogy a további három szolgáltatási jellemzőt (nem elválasztható, nem megfogható, heterogén) is feloldva, a piaci vállalkozó szempontjából nézze a felsőoktatási tevékenységet, mint terméket. Amellett érvel, hogy az egyetem, mint egy sajátos gyár alapul vétele, és az üzleti életben sikeres logisztikai, ellátási lánc menedzsmentbeli és készletezési módszerek alkalmazása egyrészt egy újfajta egyetemi formának nyithat teret a XXI. században, másrészt hatékonyabbá, sőt hatásosabbá teheti a hagyományos egyetemi rendszereket.

A tanulmány hátterében meghúzódó alapgondolat nevezetesen, hogy a gazdaságban bekövetkezett fejlődés szétterüljön az egész társadalomban, végigkíséri a felsőoktatás fejlődését is. A pedagógiában bekövetkezett változások, a tanítási módszerek fejlődése ezt hủen tükrözi. Ha azonban az előttünk álló időszakra gondolunk, akkor azt kell megállapítanunk, hogy divatos szóval paradigmaváltás kapujában vagyunk.

Az ipari társadalom több száz éves regnálása hozta a nyugati világ óriási fejlődését, amellyel vezető szerepre tett szert a világban. Ugyanakkor ez a világ lakosságának csak 15-20 százalékát érinti, minthogy a demográfiai helyzet változása következtében a fejlődő világ országai túlnépesedési problémával küzdenek. A közel-keleti és észak-afrikai államokban például a lakosság egy harmada 15 év alatti. Az Egyesült Arab Emirátusban a lakosság 40 százaléka 24 évesnél fiatalabb (Al-Kram - Ashencaen, 2004). Miközben a XX. század végén a világ fejlettebb részén a posztindusztriális társadalomról kezdtek beszélni, addig egyes ázsiai és afrikai országok, országrészek még az ipari társadalom előtti állapotban szenvednek.

Néhány évtizednek el kellett telnie ahhoz, hogy a tudósok is megértsék milyen társadalmi formáció is követi majd az ipari társadalmat. Ma már a kutatók számára többnyire egyértelmű, hogy a csupán „tagadáson", meghaladáson alapuló posztindusztriális jelző helyett célszerűbb a XXI. századot a fejlett nyugati társadalmakban az információs vagy tudásalapú társadalomnak nevezni. Jóllehet utólag visszagondolva ez a felismerés triviálisnak látszik, és a politikusok, kormányzati szakemberek szótárában gyakran már az unalomig hangoztatott, az igazi megértése azonban a legtöbb helyen még várat magára. Nevezetesen a felismerésnek az a foka, amely tettekben is megnyilvánul.

Ha csupán az egyik legátfogóbb makrogazdasági mutatót a $G D P$-ból a $K+F$-re fordított crányt nézzük, akkor azt látjuk, hogy a feltörekvő és fejlődő országok nagy lemaradásban vannak. Az Európai Unióban, az európai térség globális versenyképességét növelni 
akaró Lisszaboni Nyilatkozat szerint 2000-ről 2010-re a $\mathrm{K}+\mathrm{F}$-re fordított költségnek minden tagállamban el kellene érnie a 3 százalékot. Ezzel ellentétben Magyarországon a 2000. évi 1,1 százalékkal szemben alig egy százalékot tesz ki ez az arány 2005-ben, minden ellentétes irányú szándék ellenére. Az Egyesült Nemzetek Szervezete által publikált Arab Humán Fejlődési Jelentés szerint az arab államok átlagosan csak a GDP 0,2 százalékát fordítják kutatásra és fejlesztésre.

Ahhoz, hogy ezek az arányok megváltozzanak szerteágazó intézkedési sorozatra van szükség. Ezek között kiemelt szerepet kell játszania a felsőoktatásnak, azaz a felsőoktatás korszerüsítésének. Annak ellenére, hogy az információs társadalomban a globálissá váló világban, a tudományos eredményekhez elvileg mindenki könnyen hozzájuthat, ez a hozzáférés azonban a gyakorlatban egyenlőtlenül valósult meg. Ahogy a gazdaságban a polarizáció szemtanúi lehettünk, azaz a szegények relatíve még szegényebbek és a gazdagok még gazdagabbak lettek, ugyanúgy a tudományban is nagyfokú szegregáció következett be. Ennek hatására a tudományos eredmények többsége a fejlett nyugati világban, elsősorban az Egyesült Államokban született. Nem véletlen, hogy az USA rendelkezik a legfejlettebb oktatási rendszerrel is, amelyben az elmúlt néhány évtizedben több millió fejlődő országbeli, elsősorban ázsiai diák szerzett diplomát. Az ázsiai kis tigrisek gazdasági növekedésében empirikusan is tetten érhető az oktatási rendszer kiemelt szerepének a befolyásoló hatása.

$\mathrm{Az}$ összetett humán tőke közgazdasági kategóriában hangsúlyosan jelenik meg a felsőoktatás. Leggyakrabban két mutatós ‘ámmal szokták ezt kifejezni. Egyrészt a 18-23 éves korosztályon belül a felsőoktatási intézményekben tan'ıló hallgatók arányával. Ez a mutató a legfejlettebb államokban ötven százalék feletti, míg a fejlődő világban tíz százalék alatt van. A másik leggyakrabban használt mutató az egész felnőtt lakosságon belül vizsgálja az egyetemi diplomával rendelkezők arányát. Itt a 15-20 százalék számít vízválasztónak, ami nagymértékben a lakosság demográfiai jellemzőitől függ.

Végül is az aktív diplomások határozzák meg, hogy a gazdaság milyen fejlettséget ér el. A közgazdászok körében is vitatott, hogy milyen közvetlen hatást fejt ki a gazdaságra a felsőoktatásban tanulók számának növekedése. A Belfild (2006) által szerkesztett kétkötetes mũ, az oktatási közgazdaságtan modern klasszikusainak cikkeivel, széles teret szentel az eltérő nézeteknek.

A magunk részéről elfogadjuk azt az érvelést, amit Hanushek (2005) is képvisel, miszerint az abszolút számokkal, a beiskolázási arányokkal, a diplomások számával egyenrangúan kell kezelni az oktatás mi- nóségét. Ez az a pont, ahol a modern menedzsment eszközei, amelyek a XX. században alapvetően az üzleti szférában teljesedtek ki, sikeres alkalmazásra számíthatnak az oktatásban és különösen a felsőoktatásban. Miként az üzleti életben a termékek, szolgáltatások világkereskedelme jelezte leginkább azt, hogy versenyképesek a vállalatok ugyanúgy a múltban a diákok nemzetközi áramlása jelezte leginkább, hogy mely egyetemek voltak versenyképesek. Az analógia azonban folytatható. Miként az ipari társadalomban az export mellett megjelent a licencátadás, a közös gyártás, a termelés kihelyezése és a külföldi vállalatok alapítása is, ugyanígy ezek logikai megfelelőivel számolnunk kell a felsőoktatásban is a XXI. században.

Erre mutat példát a Dubai Tudás Faluként megalakult új felsőoktatási központ (hub), amit nevezhetünk felsőoktatási logisztikai központnak is (vagy angol elnevezéssel a logistics hub mintájára felsőoktatási hubnak).

\section{A felsőoktatás fejlődése a nemzetköziesedés szempontjából}

A felsőoktatás drámai változásokon fog átmenni a XXI. század első felében. Az érett, legfejlettebb gazdaságok, mint az USA, Kanada, Anglia és Németország harcolnak a globális versenyképességük megőrzéséért, miközben a fejlődő, felzárkózó gazdaságok új megoldásokat keresnek annak érdekében, hogy létrehozzák saját versenyképes felsőoktatásukat. Megközelítőleg kétmillió egyetemista tanult külföldi országban 2005-ben, a világ összes felsőoktatási intézményében tanuló százmillió hallgatóból. Az Egyesült Államok a legnagyobb fogadó ország, míg Kína a legnagyobb küldő ország a nemzetközi diákmobilitásban (Davis, 2003). A fogadó országok rangsorában az Egyesült Királyság, Németország és Franciaország következik, míg a legnagyobb vásárló országok piacán Korea, India és Japán a sorrend.

Az Institute of International Education által 2003ban kiadott diákmobilitási térkép részletesen elemzi a húsz legnagyobb fogadó ország és a 75 legnagyobb küldő ország statisztikai jellemzőit. A számok önmagukban is érdekesek, de még inkább lenyűgözőek a trendek, valamint a jövőre vonatkozó elképzelések. Miután az adatok 2000-re vonatkoznak és az elmúlt időszakban is lényeges változások következtek be, ezért csupán a témánk szempontjából fontos trendekre, valamint előrejelzésekre hívjuk fel a figyelmet.

A felsőoktatás a fejlett országokban tömegszerüvé vált, és a korábban jelzett ötven százalékos beiskolázottsági arány mellett (ami a 18-23 éves korosztályra 
vonatkozik) stabilizálódni látszik. A lakosság számában várható csökkenés következtében 2010 után nem várható, hogy a nappali képzésben több hallgató jelenjen meg az adott nemzet piacán. A külföldi hallgatók jelenthetik a növekedés egyetlen lehetőségét, ha a posztgraduális kiegészítő képzésektől most eltekintünk.

Az USA vezető szerepét a következő húsz évre az garantálja, hogy:

- egyetemei a legjobbak a világon, bármilyen dimenzió mentén is rangsoroljuk őket,

- a külföldön tanuló hallgatók több mint egynegyede (közel 600000 fő) jelenleg is az USA-ban található, ami majdnem háromszorosa a második helyen lévő Anglia külföldi diákjainak,

- az USA-ban tanul a legtöbb ázsiai diák, ahonnan a demográfiai robbanás miatt a jövőben a legtöbb egyetemi korú hallgató kerül ki, és ahol a legnagyobb lesz a gazdasági növekedés.

Amennyiben a felsőoktatásban tanuló hallgatók számát a demográfiai adatokból akarjuk becsülni, akkor a legegyszerűbben az összlakossághoz viszonyitott arányokból érdemes kiindulni. A legfejlettebb USAban a 300 milliós lakosságra 15 millió felsőoktatásban tanuló hallgató jut (Davis, 2003). Ez 5 százaléknak felel meg. Kínában 2005-ben történelmi jellegű esemény következett be. Az egyetemi hallgatók száma elérte a 16 milliót, amivel a világ legnagyobb felsőoktatási iparát (legalábbis a hallgatói létszám alapján) mondhatja magáénak. 1998-tól indulva megháromszorozódott az újonnan felvett hallgatók száma (Daniel Kanwar - Uwalic - Trumbic, 2006). Mindezek mellett az 1,2 milliárd lakosságra vetítve a 16 milliót, 1,33 százalékot kapunk. A tehetősebb kínai szülők továbbra is külföldre küldik gyermekeiket, de az összes kínai hallgatónak egyre kisebb aránya fog külföldön tanulni.

Ha a hallgatói mobilitás növekedésében jelẹntős potenciállal rendelkező országok, mint India, Mexikó, Malajzia, Indonézia, Brazília stb. adatait is számba vesszük, akkor optimista becslések szerint a külföldön tanuló hallgatók száma évtizedenként megduplázódhat. 2015re négymillió, 2025-re pedig nyolcmillió külföldi halîgatóval lehet számolni az addigra kétszázmilliós nagyságúra növekedett hallgatóságon belül·(Davis, 2003).

\section{A felsőoktatás versenyképessége, profit, nonprofit és állami intézmények versenye}

A felsőoktatás globálissá válása fokozza a versenyt az egyetemek között. A verseny nagyobb teljesítményekre sarkall, ami a gazdasági növekedés hajtóereje lehet. A hallgatói számok abszolút értékben vett nö- vekedése és az európai:felsőoktatás viszonylagos stagnálása mellett felmerül a kérdés: mi fog történni az elkövetkező évtizedekben? Megmarad-c az európai felsőoktatás azon a szinten, ahogyan a XIX. században kialakult, avagy megértve az idők szavát a piac is nagyobb szerepet kap az irányításban? Három olyan tényezőt szeretnénk kiemelni, amelyek a viták középpontjában vannak, amelyekről nagyon megoszlanak a vélemények, de amelyekről a tudományos és empirikus vizsgálatok elég egyértelmű következtetéseket vontak le. A három témakört egy-egy tézisszerű megállapítással jellemezném.

a) Legyenek bármilyen tulajdonviszonyok, a piaci orientáció erősítésére van szükség a felsőoktatásban.

A felsőoktatás működésével kapcsolatban a viták gyakran a magán és az állami intézmények szembeállításán feneklettek meg. Egyesek szerint az oktatás különleges áru, minden állampolgárnak elemi joga, hogy hozzájusson, függetlenül attól, hogy anyagilag megengedheti-e vagy sem. A társadalom érdeke az, hogy minden állampolgára megszerezhesse. Ebből a megfontolásból adódóan állami kézben kell tartani az ügyet. Ezzel szemben mások a tömegoktatás korában már nem fogadják el, hogy a felsőoktatás csak és döntően a társadalom számára hoz hasznot, hanem úgy ítélik meg, hogy döntően az egyén számára hoz nyereséget. Így más, piacon kapható javakhoz hasonlóan itt is ajánlatos a piaci mechanizmus érvényesítése. A The Economist 2005 szeptemberében „The brains business” címmel a globális felsőoktatásról készített vizsgálatában arra a következtetésre jut, hogy „a piacorientáltabb felsőoktatási rendszer sokkal nagyobb teljesítményre képes, mint az állam által dominált rendszer”.

Másokhoz hasonlóan a The Economist is megállapítja, hogy a hangzatos európai uniós Lisszaboni Nyilatkozat ellenére az európai felsőoktatási térség az elmúlt öt esztendőben növekedési dinamikáját tekintve elmaradt az Egyesült Államoktól, de különösen az ázsiai országoktól. Az egyetemek nagyfokú autonómiát élvezve magukkal vannak elfoglalva. Gondolkodásuk középpontjában a legnagyobb költségtényezőt jelentő egyetemi oktató áll. Ezzel szemben a piacorientáció azt jelentené, hogy a vevoororientáció és a versenytárs-orientáció határozza meg az intézmény működését. Ennek alárendelten kellene meghatározni. kialakítani a müködési, szervezeti rendszert (Barakonyi, 2004). Megjegyezzük, hogy ez a felismerés az üzleti életben sem automatikus. Éppen ezért foglalkozik sok kutatás (Kirca et al., 2005) azzal. hogy miként lehet a cégek piacorientációját fokozni. A különbség 
csupán az, hogy míg az üzleti életben a nem piacorientált vállalkozások nagy valószínűséggel tönkremennek, addig az oktatásban fennmaradnak.

b) A versenyképességet globális szinten mérik, amit a határok lebontása csak fokoz.

Egy gazdaság növekedési potenciálját a versenyképesség nagymértékben meghatározza. „A versenyképesség. az intézmények, politikák és egyéb tényezők olyan összessége, amely a jelenben és középtávon is fenntartható gazdasági prosperitáshoz vezet" (Sala-IMartin - Artadi, 2005). A különböző versenyképességi mutatószámok alapján képzett nemzeti rangsorok (mint a davosi Világgazdasági Fórumra készített tanulmány a Harvard Egyetem részéről, vagy a svájci IMD tanulmány) valamilyen szinten az oktatási rendszer állapotát is figyelembe veszik.

Megfontolandó a porteri versenystratégiák közül a költségminimalizáló, illetve a differenciáló (megkülönböztető) stratégia ütköztetése a globális felsőoktatási piacon. Abból a tényből adódóan, hogy a relative szegény ázsiai országok diákjai leginkább a legdrágább és legnagyobb változatosságot mutató amerikai egyetemeket választották, az következik, hogy a differenciáló stratégia jelentette a versenyelőnyt. Úgy ítéljük meg, hogy a jövőben nagyobb hangsúly helyeződik a költségminimalizálásia. Ennek oka, hogy a helyi ázsiai egyetemek választéka, kínálata megnő, másrészt arányait tekintve kimerülőben van az a fizetőképes szülői kör, amely megengedheti, hogy külföldre küldje gyermekét. A p aci méret adta lehetőség az is, hogy a globális egyetemek. a multinacionális vállalatokhoz hasonlóan, kihelyøzett campusok, közös képzések, licencátadások útján külföldre helyezzék tevékenységüket.

c) A felsőoktatás finanszirozásában a magán és az állami hozzájárulásnak egyaránt meg kell jelennie.

A legsikeresebb amerikai felsőoktatási rendszer azt mutatja, hogy a magán és a közintézmények egyre inkább konvergálnak. Vannak állami üzleti iskolák, ahol az állam csupán tíz százalékkal járul hozzá az intézmény költségvetéséhez. Ebből adódóan a vevő, a hallgató szempontjából majdnem fikció, hogy állami vagy magánintézménybe jár. A tandịi a kiváló állami intézményben meghaladhatja sok magánintézmény tandíját. Másrészt a magánintézmények gyakran tandíjmentességet biztosítanak a szegény családból származó kiváló hallgatóknak. Európában a tandíj kérdése tabu téma a politikusok számára. Nagy kockázatot vál- lal az, aki megfelelő (van ilyen?) előkészítés nélkül vág bele a tandíj bevezetésébe. A probléma gyakran az, miként Magyarországon is, hogy a kormányzat nem stratégiai szinten, az egész felsőoktatás versenyképességének emelése részeként vezeti be a tandíjat, hanem a költségvetési túlköltekezés ellensúlyozásaként. Így viszont elsikkad az az empirikusan bizonyítható tény, hogy a teljesen ingyenes szolgáltatás a vélt társadalmi méltányosság helyett a szegényebb adófizetők kárára valósul meg (Ferreira, 2001). Sok vitát váltott ki a finanszírozási rendszer megváltoztatása Angliában, amelynek eredményeként 2006-tól 0-tól 3000 fontig terjedő összeget kell fizetniük a diákoknak évente, Nicholas Bar szerint más országoknak is ajánlható bevezetésre. A London School of Economics professzora szerint: „ha tisztességtelennek tartjuk, hogy az egyetemi diákoktól azt kérjük, hogy többel járuljanak hozzá a felsőoktatás költségeihez, akkor még inkább tisztességtelen ugyanezt kérni a nem egyetemista adófizetőktől" (Barr, 2005).

Eddigi gondolatmentünket folytatva és a tanulmány később kifejtendő tételeit megelőlegezve, az l. ábrán három olyan egyetemi modellt vázolunk fel, amelyek egyidejűleg léteznek ugyan, de térben és időben különböző módon jelennek meg. Nyolc fogalmat használunk annak érzékeltetésére, hogy milyen hangsúlybeli eltérések vannak az egyes modellek között. Minden szónak gazdag jelentéstartalma van, és nagymértékben átfednek egymással. Ugyanakkor, mint „hívószavak” alkalmasak arra is, hogy az egyes modelleket megkülönböztessék egymástól. A következőkben röviden jellemezzük az egyes modellek legmarkánsabb sajátosságait.

A hagyományos vagy elit egyetem az ókori és a középkori szerződések nyomán a felvilágosodás kori eszmék hatására a XIX. században érte el fénykorát. A törvénybe foglalt autonómia, a humboldti, németországi (porosz) egyetemi lét központi figurája a PROFESSZOR, aki széles körű tudására alapozva OKTAT. Az oktatás vagy „,kioktatás” szóban benne van, hogy a tanár töbচ̋t tud a diákjánál, ennek következtében tudományos kérdésekben fellebbezhetetlen igazságok kimondója. (Majdnem úgy, mint a római egyház, amely hittételi kérdésekben tévedhetetlen.) A profeszszor idejének nagy részét a KUTATÁS köti le, minden mást ennek rendel alá.

A globális kapitalizmus XX. századi történetének legnagyobb nyertese az Amerikai Egyesült Államok. A sikerben óriási szerepe volt a modern piacgazdaságnak. Erre is visszavezethetơ, hogy az európai egyetemi hagyományokat továbbfejlesztve a piacorientált egyetemen a PIAC vált a legfőbb rendezőerővé. Az a tanári 
és hallgatói piac, ahol az országon belüli mobilitás természetes, ahol mind a tanár, mind a diák többször felteszi magának (egyetemének) a kérdést: mi mibe kerül? Miért éri meg egy adott egyetemen tanulni, kutatni? Ha a válasz nem kielégítő, akkor van másik lehetőség elhelyezkedésre, tanulásra. Egy kétmilliós Szlovénia vagy a tízmilliós Magyarország tanárai/diákjai számára az anyanyelven való tanítás/tanulás lehetőségei meglehetősen behatároltak. A 300 milliós, döntően angolul beszélő USA-ban más a helyzet. A választást nagymértékben meghatározza az INFRASTRUKTÚRA. Az amerikai campusok így váltak egy életforma megtestesítőivé. Ahol tanulni, kutatni, szórakozni, sportolni, azaz ,élni” lehet.

1. ábra

Versenyképességi modellek jellemzői a felsőoktatásban

\begin{tabular}{|c|c|c|}
\hline $\begin{array}{c}\text { Hagyományos } \\
\text { (elit) egyetem }\end{array}$ & $\begin{array}{c}\text { Piacorientált } \\
\text { egyetem } \\
\text { PROFESSZOR }\end{array}$ & $\begin{array}{c}\text { Menedzsment- } \\
\text { vezérelt egyetem } \\
\text { Professzor }\end{array}$ \\
\hline Diák & Diák & Diák \\
Piac & PIAC & Piac \\
Kutatás & Kutatás & Kutatás \\
Oktatás & Oktatás & Oktatás \\
\hline Tanulás & Tanulás & TANULÁS \\
\hline Infrastruktúra & Infrastruktúra & Infrastruktúra \\
Adminisztráció & Adminisztráció & Adminisztrácio \\
\hline
\end{tabular}

$\mathrm{Az}$ egyetemek harmadik modelljének a menedzsmentvezérelt egyetemnek a létrejöttét az információs társadalom beköszöntése kényszerítette/kényszeríti ki. Ez lehet a XXI. század domináns modellje. A piacgazdaság „,melléktermékeként” a XX. században az üzleti szférában létrejött a menedzsmenttudomány.

Ennek egyik legjelesebb képviselője (létrehozója) Peter Drucker is azt vizionálta, hogy a menedzsmenttudomány alkalmazható lesz a közszférában is, mint az egészségügyben, felsőoktatásban. Ehhez pedig az kell, hogy maga a gyógyítás, vagy a felsőoktatạ́s esetén a TANULÁS, mint termelési folyamat álljon a középpontban. Míg az oktatás, tanítás esetén a tanár szerepe volt a meghatározó (elit egyetem), addig a tanulás a DIÁKOT állítja a fókuszba. Az igazi kérdés az, hogy bármilyen tudással felvértezve érkezik a hallgató az egyetemre, hogyan lehet azt növelni. Hogyan lehet a hallgató értékét emelni. Ebből a szempontból egy vi- déki főiskola sokkal eredményesebb lehet. mint egy elit, világhírű egyetem. Ehbez azonban komoly folyamatszabályozásra és minőségellenőrzésre van szükség. Ezt pedig egy professzionális ADMINISZTRÁCIÓ képes csak megvalósítani.

\section{A Dubai Knowledge Village}

A felsőoktatási rendszer fejlődésének természetes velejárója, hogy nagyon sok sikeres egyedi példával találkozhatunk. A kérdés az, hogy az egyedi példák csupán az adott helyzetben, időpontban, körülmények között alkalmazhatók, vagy tágabb körben általánosítható tanulságokkal is járnak. Ez utóbbi szándéktól vezérelve mutatjuk be a Dubai Knowledge Village kezdeményezést.

Dubai az Egyesült Arab Emirátus központja megfogalmazott egy víziót arra vonatkozóan, hogy miként lehetne az olajra és a gázra épülő hagyományos gazdaságot a „tudás gazdaságává" változtatni. A DKV-t a Dubai Technológiai és Média Szabadkereskedelmi Zónában hozták létre, amely 700 nemzetközi információs és számítógép-technológiai cégnek, mint a Microsoft, az IBM, a Cisco nyújt otthont, amelyek együttesen 14000 tudás munkást alkalmaznak. Ezen túlmenően még további 850 médiavállalat (mint $\mathrm{CNN}$, Reuters stb.) is működik a zónában, 15000 tudásmunkás alkalmazottal.

Ez a háttér, valamint az olajkincs jövőben bekövetkező kifogyása utáni időszakra való felkészülés késztette a várost, illetve annak üzleti vállalkozóit arra, hogy egy új egyetem ïzleti koncepcióját felvázolják. Előzetesen számba vették mindazokat a tényezőket, amelyek korlátozzák az arab világ felzárkózását a fejlett világhoz. Ezek közül csak címszószerūen említünk néhányat, amelyek az adott régiót sújtják:

- a meglévő egyetemek rosszul felszereltek, az informatikai és könyvtári infrastruktúra fejletlen, a programok túlzsúfoltak, a tanárok rosszul fizetettek,

- a jövedelmek eloszlása egyenlőtlen, vannak nagyon szegény rétegek, a túlnépesedés, valamint a munkanélküliség és a magas írástudatlanság megfelelő oktatási intézmények nélkül konzerválja a szegénységet,

- kevés a tudományra és technológiára szakosodott hallgató, míg Koreában minden 5., az arab diákok között minden 20. választott ilyen szakirányt,

- az akadémiai intézmények elszakadtak az ipartól, termeléstől, így az üzleti szféra sem mutatott érdeklôdést az oktatási szektor iránt,

- érvényesül a (brain drain), az agyelszívás, egyes években az arab egyetemeken végzettek 25 százaléka is más-országba emigrált, 
- a szeptember 11-i események óta csökkent a tengerentúli egyetemekre jelentkezők és bejutók száma,

- a külföldi egyetemeken való tanulás költségei növekedtek: egy hároméves fokozat megszerzése Angliában 85000 dollárba is kerülhet.

Így fogalmazódott meg 2002-ben a dubai kormányzat „Vízió 2010” nevű 8 éves gazdasági stratégiai terve. Ennek része a Dubai Knowledge Village (DKV) létrehozása, amely más tudásalapú iparágakkal együtt az ország GDP-jének 25 százalékát fogja eredményezni 2010-ben.

A fenti cél érdekében a DKV 2003-ban 100000 m²es oktatási és ahhoz kapcsolódó infrastruktúrával rendelkező egyetemvárost hozott létre. A nemzetközi igényeket kielégítő létesítménybe kilenc országból (Ausztrália, India, Pakisztán, Irán, Oroszország, Belgium, Anglia, Írország és Kanada) 15 egyetemet hívtak meg, amelyek a DKV-ban egyedi szerződés alapján diplomát nyújtó programokat kínálnak. Az első tanévben 2500, míg a második 2004-2005-ös tanévben 6000 diák regisztrált, akik közül 15, illetve 30 százalék nem Dubaiból származott. A DKV terve, hogy 2010-re Dubait világszínvonalú oktatási célponttá fejlesszék. Az itt tanuló 50000 diák 90 százaléka a tervek szerint a régióból, illetve más külföldi országból származik.

\section{Szolgáltatások és fizikai termékek}

A Dubai Tudás Falu felépítése egy zöldmezős beruházásra emlékeztet, amit az IBM, a Suzuki vagy bármely nagy multinacion.ilis cég szinte folyamatosan végez a világ valamely részén. A számítógépek vagy az autók gyártásánál természetesnek tekintjük, hogy egy üzleti terv alapján beindult beruházás eredményeként, egy megadott időszakon belül legurulnának az összeszerelő szalagról a 10-20000 dollárt érő autók. Ugyanakkor természetellenesnek hat, ha egy üzleti terv eredményeként 3 év után a DKV-ből, egy előzmények nélküli egyetemvárosból, 2000 diák távozik a 30-40 000 dollárt érő diplomájával, illetve tudással. Márpedig ez történik Dubaiban, azaz az üzleti vállalkozásoknál bevált üzleti modellre épül a DKV.

Az elmúlt 30-50 éves fejlődés eredménye, hogy a GDP háromnegyedét már a szolgáltató szektorban és nem az ipari üzemekben, gyárakban termelik a fejlett országokban. A hagyományos, fizikai termékeket előállító vállalatok és a szolgáltató intézmények működési különbségeit a szakértők (Kasper et al., 2006) előszeretettel vezették vissza a fizikai javakban és a szolgáltatási termékekben meglévő különbségekre.
Ezek:

- a megfoghatatlanság,

- az elválaszthatatlanság,

- a heterogenitás,

- a romlandóság.

Annak ellenére, hogy már a kezdetektől szakmai vita illette azt a törekvést, amely a fizikai termékektől ilyen jellemzők mentén választotta el a szolgáltatást, mégis az elmúlt két évtizedben külön irodalma alakult ki annak, hogy a szolgáltatások esetén miként (azaz másként) lehet alkalmazni a menedzsmentet és a marketinget (Christopher,1998; Kasper et al., 2006). Most jött el viszont az ideje annak, hogy a ma már korlátként ható sajátosságokat lazítsuk. A Journal of Marketing 2005 októberi számában 14 neves marketingtudós arról fejti ki véleményét, hogy a marketingtudomány és gyakorlat is átmeneti állapotban van, és a tudomány határainak új meghúzására van szükség. Lehetőségként, de egyben szükségszerűségként is fogalmazzák meg az igényt a marketinggondolkodás, -gyakorlat és -infrastruktúra fejlesztésére, azaz a marketing reneszánszának, megújulásának szükségszerūségére (Marketing Reneiassance, 2005).

Ennek szellemében fogant Vargo - Lusch (2004) tanulmánya, amelyben mítosznak nevezik a szolgáltatási marketing négy jellemzőjét. Széles körű szakirodalomra támaszkodva tulajdonképpen csak ők mondják ki szisztematikusan, kategorikusan azt, amit már nagyon sokan leírtak korábban. A marketing központi gondolata a csere. Az árucserében azonban mindig, egyidejűleg van szükség valamilyen megfogható, fizikai valóságában is létező dologra, valamint fizikailag nem megfogható, de objektíve ugyanúgy létező ún. szolgáltatásra. Sok klasszikust idéznek, akik ezt a kettősséget már régen felismerték és jól kezelték. Kotler szerint „a fizikai termékek fontossága elsősorban nem a birtoklásukban van, hanem sokkal inkább a megszerzésuik révén nyújtott szolgáltatásokban" (Kotler, 1997: 8. o.).

Hasonlóképpen vélekedik Edit Pensore, az erőforrás-alapú vállalatelmélet egyik megalapítója, aki a vállalątok gazdasági növekedését kutatta. „Szigorúan véve, sohasem maguk az erőforrások képezik az ,inputot" a termelési folyamatban, hanem csupán azok a szolgáltatások, amelyeket az erőforrások nyújtani képesek" (Peurose, 1959: 25. o.). Ugyanezt a logikát folytatva érvel Vargo - Lusch (2004) amellett. hogy a vevőket, fogyasztókat sohasem az érdekelte, hogy megfogható vagy megfoghatatlan javakat vesz-e igénybe, hanem, hogy azok együttesen milyen ,„szolgáltatást” 
nyújtanak számára. Ebben az értelemben a szolgáltatás fogalma nem azonos a korábban használt és a statisztikai számbavétel érdekében képzett ágazati szintű besorolási kategóriával. A szolgáltatás szó maga a cserében a vevő, a fogyasztó számára nyújtott funkciót. tevékenységet jelenti. Ez pedig mindig a „két fél” együttműködésén alapul. A legtöbbet tudó számítógép is csak egy egyszerü vas annak a vevőnek, aki nem tudja kezelni. De egy csodálatosan megtervezett és műszakilag számtalan újdonságot felvonultató autó is értéktelen lehet egy olyan vezető kezében. aki nem fogékony (tudatlan) az ilyen dolgok iránt.

A Vargo - Lusch (2004) szerzőpáros bemutatja, hogy a szolgáltatási jellemzők megkülönböztetése marketing-nézőpontból milyen korlátokkal jár, és a marketinglogika alapján milyen következtetés vonható le (I. táblázat). Tulajdonképpen leegyszerűsítve nincs másról szó, mint amit Theodor Levitt marketing-rövidlátás címmel már 1960-ban megfogalmazott. Nevezetesen, hogy a vevö és nem a termék (akár létezik fizikailag, akár nem, akár megfogható, akár nem) áll az üzleti csere és a marketing középpontjában.

A cserében érték csak úgy jön létre, ha a vevő a fogyasztás során hasznossághoz jut. Egy vevőközpontú megközelítésben ily módon a heterogenitás, nem azonos a kiszámíthatatlan minőséggel, hanem éppen ellenkezőleg azt jelzi, hogy a különböző vevők mást igényelnek és emiatt az a jó, ha minden vevő azt kapja, amire neki van szüksége. A cél a vevői testre szabás és nem a termékek standardizálása. Ez nem mond ellent annak, hogy a termelési funkció, a termelési folyama- tok leegyszerűsítése érdekében, a tömeggyártás korában standardizációra törekszik. Ezt megtehetik az egészségügyben és az oktatásban is. de sohasem lehet elfelejteni, hogy az igazi cél a vevői testre szabás.

Gondolatmenetünket azzal zárjuk, hogy az oktatás általában, de a felsőoktatás kimondottan olyan termék. ahol a vevőnek (felnőtt, döntési képességgel rendelkező diáknak) fontos szerepe van az értékteremtésben. A tanár és a diák nem egy virtuális, megfoghatatlan világban találkozik, hanem egy jól felszerelt tanteremben, amely igenis megfogható fizikai valóság. Éppen a távoktatás, levelező oktatás, internetes oktatás terén megfigyelhető illúziók szertefoszlása mutatja, hogy az információs XXI. században is azt értékelik a hús-vér diákok, ha jó infrastruktúrával rendelkeznek az egyetemek. Ha a szellemi táplálás megfelelő fizikumot biztosító sportlétesítményekkel párosul, ha az egyetemi közösségi élet a tudás elmélyítését szolgálja, azaz része magának a szolgáltatásnak. Az e téren meglévő differenciáltság az, ami a különböző profilú egyetemek számára is sikert jelenthet.

\section{Készletezés és logisztika a felsőoktatásban}

A szolgáltatás jellemzők közül az elválaszthatatlanság mítoszának tarthatatlanságát szemléltessük az autógyártás és a diplomagyártás párhuzamba állításával. $\mathrm{Az}$ autó akkor lett a fogyasztóé, ha kifizette, hazavitte és szabadon rendelkezhet vele. A diploma (illetve a diploma által szimbolizált tudás) akkor lett a hallgatóé, amikor a diplomaosztás után elhelyezkedett. A gyönyörű

1. táblázat

\section{A szolgáltatási jellemzôk megkülönböztetésének korlátai és következményei}

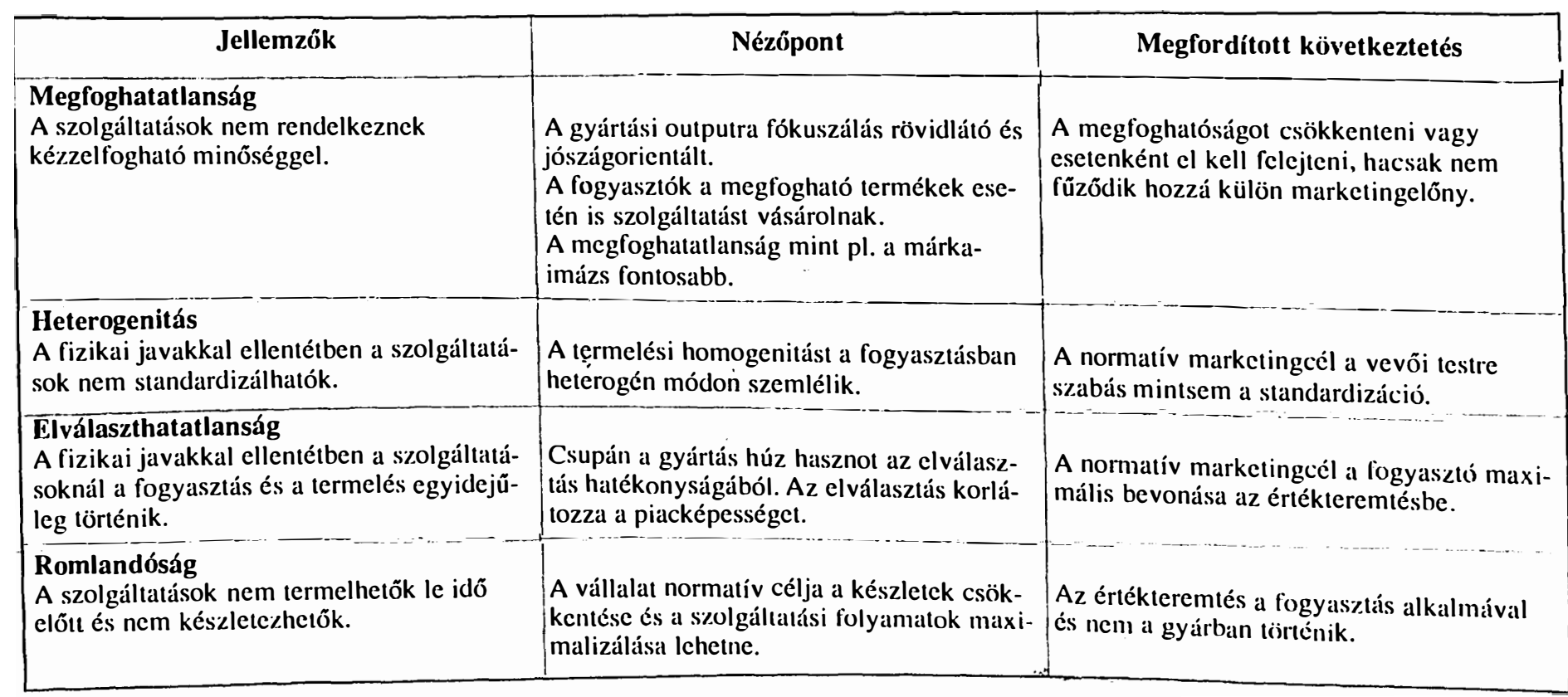

Forrás: Vargo - Lusch (2004): 327. o. 
autó látványa, miként a szépen kiállított diploma forgatása, a diplomaosztásról készített képek nézegetése azonban még nem jelenti az ,igazi” fogyasztást. Az autót azért vásároltuk, hogy beleüljünk és autózzunk. $\mathrm{Az}$ autógyűjtőket leszámítva a garázsban tartott autó nem jelent értéket a vevőnek. Ahogyan a diplomák értékét is az adja, ha a munkahelyen használni tudjuk.

Az autónkban (Mercedes márka) szuper motor van, amivel $240 \mathrm{~km} / \mathrm{h}$-s sebességgel is lehet repeszteni. Lehetne, de a közlekedési szabályok nem teszik lehetővé, kivéve Németországban, ahová viszont csak minden második évben jutunk el. Ez azt jelenti, hogy van egy tulajdonság, funkció, amit nem tudunk kihasználni, így nem hoz számunkra értéket, hiába fizettük ki az árát. A diplománk (Harvard Egyetemről) azt jelzi, hogy vállalatstratégiai kérdésekkel is foglalkozhatnánk (több ilyen kurzust is hallgattunk) a munkahelyünkön azonban, a munkaköri leírásunkban nem szerepel ilyen feladat. A vállalati klubban, informálisan megoszthatjuk ugyan ilyen tudásunkat kollégáinkkal (miként az autópályán a szabályokat megsértve gyorsabban is száguldhatunk), de ezért nem kapunk magasabb fizetést, nem jön létre igazi értékteremtés. Márpedig a marketing célja az, hogy a fogyasztót minél inkább bevonjuk az értékteremtésbe. Ugyanakkor a termelés az autógyártásnál ugyanúgy elválik a fogyasztástól, mint a diplomagyártásnál. Az a szerelő, aki a szuper motort behelyezte az autóba 2000-ben, ugyanúgy nincs velem 2006-ban az autópályán, mint ahogy az a Harvard professzor sincs mellettem 2006-ban a munkahelyemen, aki a stratégiai tervezést tanította 2000-ben.

$\mathrm{Az}$ abszurdnak, szokatlannak tűnő példákkal azt szeretném illusztrálni, hogy amikor a termelés és a fogyasztás elválaszthatatlan`ígáról beszélnek, akkor a fogyasztást a termelö szempontjából szuïken értelmezik. Az, aki havonta jár fodrászhoz, nem abban az órában „fogyasztja” a fodrász által nyújtott szolgáltatást, amikor a fodrász éppen dolgozik a fején, hanem az elkövetkező hónapban minden alkalommal, amikor pl. társaságban megjelenik és a kollégák azt mondják (látják), hogy jó a frizurája, vagy amikor belenéz a tükörbe és megállapítja, hogy ,,jól nézek ki”.

$\mathrm{Az}$ előző példák alapján, ha elfogadjuk az elválaszthatatlanság jellemző tarthatatlanságát, akkor könynyebb dolgunk van a romlandóság, a nem készletezhetőség megcáfolásával. Ismét csak a felsőoktatás példájánál maradva, nem igaz, hogy a szolgáltatások nem termelhetők le idő előtt. Miután a fogyasztás folyamat jellegü, úgy értelmetlen azt egy időponthoz kötni. A legyártott autó hónapokig állhat a termelő raktárában, mert nincs rá vevo, azaz készleten van. Ugyanúgy a friss diplomás hónapokig várhat, amíg álláshoz jut.
Miként az autógyárak számon tartják a késztermékkészleteiket, ugyanúgy a piacorientált amerikai üzleti iskolák számon tartják az elhelyezkedni nem tudó végzett hallgatóikat, és megtesznek mindent, hogy álláshoz juttassák őket.

Nagyon sokan egész életükben csak egy diplomával rendelkeznek, sokkal többen vannak, mint azok, akik egész életükben egy autóval beérik. Más szóval a romlandóság sokkal inkább fennáll a fizikai terméknél (autó), mint a szolgáltatásnál (diploma). Ha a termelési folyamatba megyiink bele, akkor egy autóalkatrész hiánya az abban az időpontban legyártható autót végérvényesen meg nem történtté teszi. Ugyanúgy egy adott napon meg nem tartott előadás soha nem tartható meg. Ettől még a hallgató meg fogja kapni a diplomáját, miként az autógyár is képes tartani a termelési tervét.

A DKV létrehozása sok közös jegyet mutat az ipari és logisztikai központok kialakításával. Jó példát mutat erre az, ahogyan Koreában az Incheon Nemzetközi Repiilótérre tervezik egy globális, logisztikai és gazdasági hub (központ) létrehozását. Az indok, hogy a kormányzat csak kevésbé támogatja az áruszállítást, szemben a személyszállítással. Így a dinamikusan növekvő koreai gazdaságnak üzleti alapon, a szinergikus hatásokat kihasználva érdemes stratégiát kidolgozni. Erre mutat példát Lee és Yang (2003) tanulmánya. Ebben egy szuper központ (hub) tervét vázolják fel, amely a légi szállítás mellett a logisztikának és a nemzetközi üzleti tevékenységnek is helyet ad. A regionális klaszter modell a fokozatos fejlesztésre épít, ahova más kapcsolódó iparágak is betelepedhetnek. Ahhoz, hogy a repülőtérből a vámszabad területen müködő, hatékony hub váljon, a díjakat és a kapcsolódó logisztikai költségeket minimalizálni kell, miközben agresszív marketingstratégiát folytatnak. Tevékenységüket Északkelet-Ázsiára kiterjesztve, Kína és Japán versenyével számolva tervezték meg. Támaszkodnak az erős helyi független logisztikai szolgáltatókra, miközben a multinacionális logisztikai cégeket is oda kívánják vonzani. Nem véletlen, hogy a szállítmányozó cégek mellett oktatási és kutatási cégek betelepülésére is számítanak.

Egy másik példa Kínában a Shenzeni Szabadkereskedelmi Zóna, ahol elsősorban elektronikai, informatikai, számítástechnikai cégek telepedtek meg. Most látták elérkezettnek az időt arra, hogy oktatási intézményeket is betelepítsenek a zónába. Magyarországon egy vállalkozói csoport a Szilikon Völgy mintájára a Zsámbéki-medencében tervez Talentisz néven ipari-tudományos parkot létrehozni. Ebben a tervben is szerepel oktatási intézmény betelepítése. Mindezek a példák azt sejtetik, hogy az oktatási szolgáltatási tevé- 
kenységeket ezek a befektetők tabuktól mentesen, üzleti alapon, más logisztikai, termelési folyamatokhoz hasonlóan fogják megszervezni.

Visszatérve a DKV-hez, a helyi szervezők úgy állapodtak meg a beszállító egyetemekkel, hogy azok garantálják a termék (a diploma) azonosságát az anyaegyetemen kiadott diplomával. A gyártási, technológiai tervet helyettesítő tanterv alapján kibocsátási tervet készítenek, hogy évente hány hallgatót vesznek fel. A minőségi színvonalat biztosítja, hogy az órák legalább 50 százalékát az anyaegyetem által szervezett tanárok tartják, akik a világ minden részéről jöhetnek, és általában 1-3 hetes blokkokban tanítanak. Az oktató tanárok jelentős részét ily módon a beszállító egyetemek „készletezik”, akiknek az ily módon felmerülő készletezési költségeit is ők állják.

A Dubai Tudás Falu hallgatói élik a tudásmunkások életét. Szakmai gyakorlaton vesznek részt, projekteken dolgoznak, vizsgáznak, sportolnak, kulturális életet élnek, diákközösséget üzemeltetnek, és mindent megtesznek annak érdekében, hogy a diplomájuk sokat érjen, azaz jól tudjanak elhelyezkedni. Egy profeszszionális adminisztratív gárda szervezi, felügyeli a munkájukat, és fogja majd nyomon követni a szakmai pályájukat, az igazi értékesülési folyamatot a végzés után. Mint a volt diákegyesület tagjai, akkor fejezik ki legegyértelműbben megelégedésüket, ha az Alma Matert adománnyal látják el.

\section{Következtetések}

Tanulmányunkban a felsőoktatási piac növekedési trendjeit vizsgálva, a fejlődő, felzárkozó országok lehetőségeit kutattuk a versenyképesség szempontjából. Azt találtuk, hogy az európai felsőoktatási térség lisszaboni céljai kudarcra vannak ítélve, ha Európa továbbra is kizárólag a XIX. századi humboldti egyetemi modellre építve akar fejlődni, és nem teszi lehetővé más modellek alkalmazását. A legsikeresebb amerikai felsőoktatási modell egyértelmúen mutatja a piacorientáció előnyét a tömegoktatás korában. Oly módon tud a tömegek számára jó minőségű oktatást nyújtani, hogy közben az elitképzésben is élen jár, amit az amerikai egyetemek kutatási eredményei bizonyítanak a legnyilvánvalóbban.

A Dubai Tudás Falu (DKV) létesítésének kapcsán, a piacorientáció mentén végiggondoltuk, hogy milyen következményekkel jár, ha felszabadítjuk az oktatást a „különleges” termék mítoszától. Ugyanis abban látjuk a fejlődő, felzárkózó országok felsőoktatási rendszerének a kitörési lehetőségeit, ha a menedzsmenttechnikákat, amit a XX. században az üzleti szférában kifejtettek és sikeresen alkalmaztak, bátrabban alkal- mazzák. Az európai felsőoktatás a Xl. századi bolognai kezdetektől hosszú utal tett meg, és a XIX. században érte el a tetőpontját. Ennek gyümölcseit élvezte még a XX. század első felében is. Jól mutatja ezt a Humboldt Egyetem története. 1900-1956 között 29 Nobel-díjjal jutalmazták a kutatóit, azóta azonban, az elmúlt ötven évben senki sem kapott, viszont annál több amerikai egyetem (The brains Business, 2005).

Amennyiben létezik társadalmi igazságosság és méltányosság, akkor a ma még szegénységben élő négymilliárd fő, a világ lakosságának kétharmada számára is megnyílik a lehetőség a felzárkózásra. Kína és India népessége indokolja, hogy a XXI. század második felében már vezető szerepet játszanak a globális felsőoktatási piacon. Az ehhez vezető úton van szükség arra, hogy a szolgáltatást általában, de a felsőoktatást külön is a marketing szempontjából értékeljük, elfogadva Vargo és Lusch (2004) érvelését. Ezt továbbgondolva, a logisztikai menedzsment és az ellátásilánc-menedzsment filozófiát kívánjuk alkalmazni a globális felsőoktatásra. Ennek a logikának megfelelően az egyetemi oktató egy az inputok, erőforrások között, aki igenis „készletezhető” az oktatási/tanulási folyamatba történő bevonása ütemezhető, a hallgatói igényhez szabható. Az autógyártásban és más bonyolult terméket előállító iparágban használatos „anyagjegyzék” mintájára itt is van lehetőség arra, hogy listát készítsünk arról, mit is ,építettünk be egy diplomás hallgatóba. Könyvek, videók, internetoldalak, előadások, szemináriumok, szakmai gyakorlatok, külföldi tanulmányutak, klubdélutánok, partik, sportrendezvények és sorolhatnánk tovább mi minden alkotja azt a jegyzéket, amit egy tudásmunkás diplomájának tartalmaznia kell. Amitől egyik egyetem megkülönböztethető egy másiktól, amitől olcsóbb vagy drágább, akár az állam fizeti ki, akár a hallgató.

A hallgató nem általában akar tudáshoz jutni, hanem az adott piacon szeretne eladható tudást szerezni, minimális (megfizethető) költségek mellett. A felsőoktatásban a piacorientációhoz hasonló forradalomra van szükség a relatív versenyképesség növelése érdekében. $\mathrm{Az}$ alapvetően konzervatív környezet azért is alakulhatott ki, mert a meglévő intézmények valamikor sikeresek voltak és most is eredményesek helyi szinten. A nemzetközi diákmobilitás segítségével, a globális felsőoktatási központok (hubok) létrehozásával azt kívántam bemutatni, hogy a globális versenyben ezek a megoldások a helyi piacon versenyző egyetemek számára is előnyöket hordoznak.

A Logistics Europe folyóirat 2006 júliusi számában, az autógyártás logisztikáját elemezve megállapítják, hogy növekszik azon autók száma, amelyeket a 
vevői igényekre gyártanak le. Ehhez kifinomultabb ellátásilánc-menedzsmentre és készletezésre van szükség. Ezzel egy időben az International Educator 2006 májusi-júniusi számában arra a kérdésre keresik a választ, hogy az USA frissen végzett diplomásai felkészültek-e a globális versenyre. A NAFSA javaslatára a Szenátus 2006-ot a „Külföldi tanulmányok évének” nyilvánította. Annak illusztrálására, hogy a felsőoktatási hub nem is áll olyan messze a mindennapi gyakorlattól álljon itt egy idézet.

„Új, ingyenes szolgáltatást vezetett be a University of North Carolina (Wilmington), a tanárok és a nem akadémiai dolgozók számára lehetővé teszi, hogy megismerjék, megszervezzék a rövid és hosszú távú munkacserét a világ bármely részén található egyetemek között.

$\mathrm{Az}$ International Professor Exchange Web oldalt (http://uncw.edu/ipe) azért fejlesztették ki, hogy egy online hub-ként szolgáljon, ahol a professzorok és mások, akik hasonló oktatási, kutatási pozíciók iránt érdeklődnek, a nemzetközi cserében egymásra találjanak. A honlap látogatói megtekinthetik a tudományterületek, a régiók, országok és a kezdési időpontok alapján csoportosított listákat. Azok, akik bejelentkeznek tagként, hozzájutnak a számukra érdekes részletekhez, illetve ők is felhelyezhetnek „mások számára kiajánlott pozíciókat" (International Educator, 2006: 10. o.).

Magyarországon az 1970-es években az Országos Piackutató Intézet készített listát a vállalatok elfekvő készleteiről, amelyet az azonos ágazatban dolgozó vállalatok előszeretettel használtak. Egyrészt, hogy megszabaduljanak felesleges készleteiktől, másrészt, hogy a krónikus hiányt felszámolják. A módszer nem veszítette el aktualitását.

\section{Felhasznált irodalom}

Al Karam, Abdulla - Ashencaen, Andromeda (2004): Knowledge Village: Establishing a global destination for education In Dubai, 10 November, 2004, NAFSA Report, pp. 1-10.

Barakonyi Károly (2004): Rendszerváltás a felsôoktatásban, Bologna-folyamat, modernizáció, Akadémiai Kiadó
Barr, Nicholas (2005): Financing Higher Education, Finance and Development, Vol. 42, No. 2, p. 1-9, International Monetary Fund

Belfield, Clive R. (2006): Modern Classics in the Economics of Education, Volume 1-11, The International Library of Critical Writings in Economics 194, Edward Elgar

Christopher: Martin (1998): Logistics and Supply Chain Management, Strategies for Reducing Cost and Improving Services, Second Edition, Financial Times - Prentice Hall

Daniel, Iolın - Kamwar, Asha - Uvalic-Trumbic, Stamenka (2006): A Tectonic Shift in Global Higher Education, Change, July/August 2006, Vol. 38, No. 4, Source: www.carnegicfoundation.org/change

Davis, Todd M. (2003): Atlas of Student Mobility, Institute of International Education, New York

Ferreira, Francisco H. G. (2001): Education for the masses? The interaction between wealth, educational and political inequalities, Economics of Transition, Vol. 9 (2), 533-552, EBRD

Hanushek, Eric A. (2005): Why Quality Matters in Education, Finance and Development, IMF, June 2005, Vol. 42, No. 2

Kasper; Hans - Helsdingen, Piet van - Gabbott, Mark (2006): Services Marketing Management, A Strategic Perspective, Second Edition, John Wiley \& Sons

Kirca, Ahmet H. - Jayachandran, Satish - Bearden, William O. (2005): Market Orientation: A Meta-Analytic Review and Assessment of lts Antecedents and Impact on Performance, Journal of Marketing, Vol. 69 (April), 24-41.

Kotler, Philip (1997): Marketing Management, Prentice Hall

Lee, Hunsoo - Yang, Han Mo (2003): Strategies for a global logistics and economic hub: Incheon International Airport, Journal of Air Transport Management, Vol. 9, pp. 113-121.

Log On for Virtual Faculty Exchange, in: International Educator, Vol. 15, No. 3, May+June 2006, NAFSA: Association of International Educators, pp. 10.

Marketing Renaissance: Opportunities and Imperatives for Improving Marketing Thought, Practice, and Infrastructure, Journal of Marketing, Vol. 69 (October), 1-25.

Penrose, Edith (1959): The Theory of the Growth of the Firm, Third Edition With a new Foreword by the author, Oxford University Press

Sala-I-Martin, Xavier - Artadi, Elsa V. (2005): The Global Competitiveness Index, in : The Global Competitiveness Report 2004-2005, Chapter 1.3 pp. 51-80, HBS and World Economic Forum

The Automotive Supply Chain, a special report, in: Logistics Europe, July 2006, Official Journal of the European Logistics Association

The Brains Business, A survey of higher education, The Economist, September 10th 2005, pp. 3-22.

Vargo, Stephen - Lusch, Robert F. (2004): The Four Service Marketing Myths, Remnants of a Goods-Based, Manufacturing Model, Jourñal of Service Research, Vol. 6, No. 4, May, 324-335. 